\title{
A study of the Overburden dumps flora at Chernogorsky quarry
}

\author{
Eugene Ankipovich, Elena Lagunova ${ }^{*}$, Irina Barsukova, and Tatiana Leonova \\ Katanov Khakassia State University, Abakan, Russia, 655017
}

\begin{abstract}
Species composition of phytocoenoses of overburden dumps at Chernogorsky quarry has been investigated. Systematic, chorological, environmental and biomorphological analysis of flora has been carried out. It has been found that the quarry flora includes 47 species of higher vascular plants that are related to 35 genera and 16 families. $97.9 \%$ are metasperms. Asteraceae and Poaceae are the largest families. Species with Holarctic areas prevail in the chorological structure (36.2\%). In terms of soil moisture all species can be subdivided into 3 groups: mesophytes $(40.4 \%)$, mesoxerophytes $(36.2 \%)$ and xerophytes $(23.4 \%)$. The leading role in the researched flora belongs to herbaceous polycarpous plants $(57.4 \%)$, which is characteristic of all the boreal region flora. 1 species listed in the Red Books of the Republic of Khakassia was discovered in the overburden dumps (Nitraria sibirica Pallas) and 6 species which have been noted for the first time for the flora of Khakassia.
\end{abstract}

\section{Introduction}

In case of open-cut mining enormous territories are subjected to harsh technogenic impact. Chernogorsky coal-field has been mined in Khakassia since 1956. By now, the total area of the ground damaged by open-cut mining is 3200 ha. Herewith, the territory that suffers from negative consequences related to the disturbance of hydrological regime, polluting adjacent landscapes with technogenic toxicants, increased erosion, etc. is 10 times bigger than the areas of the damaged land. Destruction of technogenic landscape by wind and dispersion of unconsolidated rock fractions at the overburden dumps are dangerous environment pollution sources as well. Transformation of natural landscapes of Khakassia into industrial and anthropogenic ones happens without sufficient landscape and environmental justification and clear forecast for decreasing negative consequences for the environment. In this connection, it is highly important to study the process of flora diversity recreation at overburden dumps of different age. The purpose of this study is to ascertain special features of natural colonization by vegetation of the overburden dumps at Chernogorsky quarry. In accordance with this purpose, we set the objective to discover and analyze the species composition of phytocenoses, confined to microrelief plots of unevenaged overburden dumps.

\footnotetext{
${ }^{*}$ Corresponding author: aes-1962@yandex.ru
} 


\section{Materials and methods}

The research materials are the samples of plants collected during field trips in 2018-2019. The main research method was transecting (Transect method), covering most coal overburden dumps at Chernogorsky quarry. The gathered collections were handed over to the Herbarium of Khakass State University (HGU). The authors would like to express their gratitude to D.N. Shaulo, the Head of the Herbarium Lab of the Central Siberian Botanical Garden, SB RAS, for the kind help and consultations in the process of plant determination.

\section{Results and their discussion}

The enterprise SUEK Khakassia LLC, Chernogorsky quarry was formed on the basis of Chernogorsky hard coal field, located in the territory of Ust-Abakansky district of the Republic of Khakassia. The monitoring results demonstrate that the area of disturbed soils has increased from 2061 ha to 3168 ha over the last 25 years [1]. The studied overburden dumps are of external type and comprise a ravine stretching from East to West, which widens in the western part and is overlapped with transverse dump of ridge-like surface. The ravine height above the sea level is $402 \mathrm{~m}$, the height of the top of the overburden dump is $425 \mathrm{~m}$. 5 elements of the mesorelief stand out: plateau, the slopes of the Northern, Souhern, Western and Estern expositions. In the Western part of the lot, the ravine is complicated by smaller ravines, small closed topographic lows and hills [2]. In terms of geological structure, it is comprised of mid-carboniferous coal-bearing strata of Chernogorsky formation and modern technogenic strata. Soil-forming rock is virtually absent on the slopes and the surface of the dumps [3]. The quarry is located in Minusinsk Hollow, which is characterised by anticyclonic conditions of atmospheric circulation with the prevalence of dry, mostly cloudless weather, sudden temperature fluctuations and interchanging periods of light breezes and strong winds [4].

The flora of overburden dumps at Chernogorsky quarry includes 47 species of higher vascular plants, related to 35 genera and 16 families. By $97.9 \%$ the flora consists of angiosperms; $74.5 \%$ of these are dicotyledonous, $23.4 \%$ are monocotyledonous. Vascular sporophytes are represented by one specie Pteridium aquilinum (L.) Kuhn. The largest families within the researched flora are Asteraceae, which includes 12 species $(25.5 \%$ of the flora composition) and Poaceae, which includes 11 species (23.4\%). The most dispersed species of the Asteraceae family: Artemisia frigida Willd., A. glauca Pall. ex Willd., A. sieversiana Willd., Heteropappus altaicus (Willd.) Novopokr., Erigeron canadensis L. The high plastisity of the species of this family, and the capacity to adapt to unfavourable conditions gives them the possibility to occupy new habitats easily, including the anthropogenic ones. The Poaceae reinforce the soils of overburden dumps at the abovementioned quarry. The flowing species are widely represented: Calamagrostis epigeios L., Leymus racemosus (Trin.) K. Richt., Setaria viridis (L.) P. Beauv., Elytrigia repens L., Hordeum jubatum L.

Fabaceae, Rosaceae и Brassicaceae families contain 3 species each (6.4\%). Species of Fabaceae family are usually abundant in the steppe floras of Siberia, however, legums are scarce on overburden dumps. Synanthropic species Onobrychis arenaria (Kit.) DC. and Melilotus officinalis (L.) Pall have been discovered here. These species' biomass increases and they are able to invade large territories quickly in conditions of ruderal ecotopes, especially if they are part of a pioneer group. Astragalus atrosibiricus Schischkin is rarely found in the researched territory. Rosaceae family in the disturbed flora of overburden dumps at Chernogorsky quarry is determined by its adventive species: Physocarpus opulifolius (L.) Maxim. and Potentilla lydiae Kurbatsky. The specie Potentilla tanacetifolia Willd. ex Schlecht is encountered rather frequently. In the same way as Fabaceae, 
Brassicaceae family is represented by synanthropic species, which are spread with seeding material in ruderal habitats and includes the following species: Erisimum cheiranthoides L., Sinapis arvensis L., Sisymbrium wolgense M. Bieb. ex E. Fourn.

Chenopodiaceae, Scrophulariaceae, Solanaceae and Caryophyllaceae families are represented by 2 species each (4,3 \%). 6 families (Primulaceae, Lamiaceae, Boraginaceae, Nitrariaceae, Onagraceae, Gypolepidaceae) contain 1 specie each in the researched flora.

The analysis of the generic spectrum demonstrated that there is one multi-specific genus on the slopes of uneven-aged overburden dumps, Artemisia, which includes 8 species (17\%) (Artemisia dracunculus L., A. scoparia Waldst. et Kit., A. frigida, A. macrocephala Jacq. ex Bess., A. sieversiana, A. glauca, A. tanacetifolia L., A. vulgaris L.). The genera Potentilla, Leymus, Poa, Linaria, Solanum contain 2 species each (4.3\%). The other genera include 1 specie each. The large proportion of homotypical and species-limited genera point to the relative newness of the flora. The homotypical and byspectral genera cover $82,9 \%$ of the of the generic diversity. $61.7 \%$ of all the genera under study are homotypical. According to Tolmachev, A.I. [8], the prevalence of species-limited and, especially, homotypical genera in the particular flora can point to the fact that the given flora was to a great degree formed due to migration of species from the adjacent territories.

The chorological structure consists of 6 groups. Holarctic species prevail $(17$ species, or $36.2 \%$ from the overall number of species). The Eurasian group is represented by 13 species $(27,6 \%)$, including 3 cosmopolitan species $(6.4 \%)$. The share of the species which do not spread beyond Asia (North-Asian, Central Asian, South Siberian) is $29.8 \%$ of all the species, which is the evidence of allochthonous trends in the flora development.

Groups of plants with different relation to soil moisture are marked out for environmental analysis [5]. All the species are related to 3 ecological groups. The greatest number of species is found in the mesophytes group (19 species or $40.4 \%$ ), including Cirsium setosum (Willd.) Bieb., Inula salicina L., Convolvulus arvensis L., Androsace septentrionalis L., Linaria vulgaris Mill., Melandrium album (Mill.) Garcke, Sinapis arvensis L., Chamerion angustifolum (L.) Holub., Pteridium aquilinum (L.) Kuhn, Physocarpus opulifolius (L.) Maxim., etc. Mesoxerophytes include 17 species (36.2\%). These are such species as Potentilla tanacetifolia Willd. ex Schlecht., Onobrychis arenaria (Kit.) DC., Heteropappus altaicus, Elytrigia repens, etc. Xerophytes are represented by 11 species (23.4 \%). Linaria altaica Fisch., Nitraria sibirica Pall., Koeleria cristata (L.) Pers., Artemisia frigida, etc. belong to this ecological group.

The analysis of life forms has been carried out on the basis of I. G. Serebryakov classification [6]. In the flora under study, just as in the flora of Khakassia [7] and in the flora of the boreal region in general [8], the leading role belongs to herbaceous polycarpous plants. They comprise $57.4 \%$ of the overall number of species. The main part of perennial grasses belongs to the group of taproot plants and includes 8 species (17\%): Onobrychis arenaria, Astragalus austrosibiricus Schischkin, Lithospermum officinale L., Linaria vulgaris Mill., etc. There are 7 species of long-rooted plants $(23.6 \%)$, including mostly mesophyllous species Chamerion angustifolum, Inula salicina, Artemisia tanacetifolia, Cirsium setosum, Convolvulus arvensis L. Short-rooted plants are represented by 6 species (12.8\%) (Potentilla tanacetifolia, P. lydiae, Artemisia glauca, A. dracunculus L., Pteridium aquilinum (L.) Kuhn, Sisymbrium wolgense). Sod plants annually open not one but a great number of reproduction buds therefore large "bushes" or groves are formed [6]. Sod plants are subdivided into densely bushy and bunch-grasses, with 3 species of each $(6,4 \%)$ and belong to Poaceae family. Koeleria cristata, Psathyrostachys juncea (Fisch.) Nevski, Poa botryoides (Trin. ex Griseb.) Roshev are densely-bushy plants. Leymus dasystachys (Trin.) Pilger, Poa angustifolia L., Elytrigia repens are bunch-grasses.

Monocarpous herbs include 16 species, which comprises $34 \%$ of the overall number of species. Many of them are weeds. The most multiple representatives of annual and biennial 
plants belong to the following families: Poaceae (Hordeum jubatum, Panicium miliaceum, Setaria viridis), Lamiaceae (Leonurus tataricus L.), Caryophyllaceae (Melandrium album (Mill.) Garcke), Brassicaceae (Erisimum cheiranthoides L., Sinapis arvensis L.), Primulaceae (Androsace septentrionalis), Chenopodiaceae (Chenopodium aristatum, Salsola collina Pallas.), Solanaceae (Solanum nigrum L.), Asteraceae (Erigeron canadensis, Artemisia sieversiana, A. scoparia Waldst. et Kit.), Fabaceae (Melilotus officinalis). Arboreal and semiarborescent plants are scarce in the researched flora: 2 shrubs (4,3\%), Physocarpus opulifolius and Nitraria sibirica, subshrub Solanum dulcamara L. and dwarf subshrub Artemisia frigida.

One species from the Red Books of the Republic of Khakassia (Nitraria sibirica) has been discovered in the flora of overburden dumps at Chernogorsky quarry [9] and six species, which have not yet been observed in Khakassia before, including Physocarpus opulifolius, Potentilla lydiae, Artemisia macrocephala Jacq. ex Bess., Leymus dasystachys (Trin.) Pilger, Sisymbrium wolgense, Solanum dulcamara have also been discovered.

The work was financially supported by the grants of the Russian Foundation for Basic Research №18-44-190006 and №18-44-190007.

\section{References}

1. I.V. Zenkov, B.N.Nefedov, Yu.P. Yuronen, I.M. Baradulin, E.V. Kiryushina, V.N. Vokin, Coal., 2 (2015)

2. O.S. Safronova, T.G. Lamanova, N.V. Sheremet, Coal., 7 (2018)

3. I.V. Zenkov, B.N. Nefedov, I.M. Baradulin, V.N. Vokin, E.V. Kiryushina, Ecology and the industry of Russia, 6 (2014)

4. A.V. Kuminova, N.M. Chizhikova, M.G. Tanzybaev, The vegetation cover of Khakassia (Nauka, Novosibirsk, 1976)

5. T.G. Goryshina, Ecology of plants (Vysshaya Shkola Publishers, Moscow, 1979)

6. I.G. Serebryakov, Ecological morphology of plants. Life forms of angiosperms and coniferous plants (Vysshaya Shkola Publishers, Moscow, 1962)

7. E.S. Ankipovich, The catalogue of the flora of the Republic of Khakassia (Altay University Publishing House, Barnaul, 1999)

8. A.I. Tolmachev, Introduction into plants geography (LSU Publishing House, Leningrad, 1974)

9. The Red Books of Khakassia. Rare and endangered species of plants and mushrooms (Nauka Publishing House, Novosibirsk, 2012) 